Article

\title{
Fly Ash as an Ingredient in the Contaminated Soil Stabilization Process
}

\author{
Kamil Banaszkiewicz *(D), Tadeusz Marcinkowski and Iwona Pasiecznik
}

check for updates

Citation: Banaszkiewicz, K.;

Marcinkowski, T.; Pasiecznik, I.

Fly Ash as an Ingredient in the

Contaminated Soil Stabilization

Process. Energies 2022, 15, 565.

https://doi.org/10.3390/en15020565

Academic Editors: Robert Oleniacz and Katarzyna Grzesik

Received: 24 December 2021

Accepted: 11 January 2022

Published: 13 January 2022

Publisher's Note: MDPI stays neutral with regard to jurisdictional claims in published maps and institutional affiliations.

Copyright: (C) 2022 by the authors. Licensee MDPI, Basel, Switzerland. This article is an open access article distributed under the terms and conditions of the Creative Commons Attribution (CC BY) license (https:// creativecommons.org/licenses/by/ $4.0 /)$.
Faculty of Environmental Engineering, Wroclaw University of Science and Technology, 27 Wybrzeże Wyspiańskiego St., 50-370 Wroclaw, Poland; tadeusz.marcinkowski@pwr.edu.pl (T.M.); iwona.pasiecznik@pwr.edu.pl (I.P.)

* Correspondence: kamil.banaszkiewicz@pwr.edu.pl

\begin{abstract}
Fly ash is the main by-product of coal combustion characterized by a large specific surface area. In addition to oxides, it also contains unburned coal and trace elements. This study aimed to investigate the possibility of using fly ash from pit-coal combustion (CFA) for the treatment of benzene-contaminated soil (S). The CFA was used as a mixture with Portland cement (PC) $(70 \%$ PC $+30 \%$ CFA). The soil was treated with a PC-CFA mixture in amounts of 40,60 , and $80 \%$ of soil mass. During the process, the concentration of benzene was monitored with the flameionization detector. Produced monoliths (S+(PC-CFA)x) were tested for compressive strength and capillary water absorption. The experiment confirmed that the PC-CFA mixture limited benzene emission. The highest reduction in benzene concentration (34-39\%) was observed for samples treated with the PC-CFA mixture in an amount of $80 \%$ (S+(PC-CFA)80). The average compressive strength of monoliths S+(PC-CFA)40, S+(PC-CFA)60, and S+(PC-CFA)80 was 0.57, 4.53, and 6.79 MPa, respectively. The water absorption values were in the range of $15-22 \% \mathrm{dm}$.
\end{abstract}

Keywords: hazardous waste; VOC; physicochemical stabilization; encapsulation; remediation

\section{Introduction}

Fly ash is a type of waste generated in coal power plants. Currently, about $35 \%$ of global electricity is produced from coal [1]. The largest coal-consuming economies are China (nearly half of global coal consumption), India, and the United States. Approximately $60 \%$ of electricity in China is produced from coal [2]. In addition, in Poland, electricity production is based on fossil fuels. In $2018,48 \%$ of produced electricity came from hard coal, 29\% from lignite, 13\% from renewable sources, and 7\% from gas [3,4]. Recently, a decreasing trend in worldwide coal consumption has been observed (Figure 1). In 2020, the decrease in coal consumption was $4 \%$ [5]. The main reasons for such changes are the industrial transformation and the COVID-19 pandemic. In 2020, the world energy demand decreased by $4.5 \%$. In parallel, the $\mathrm{CO}_{2}$ emissions from energy use fell by $6.3 \%$ [5]. It is estimated that in 2021, energy and coal consumption increased by $4.1 \%$ and 5\% for G20 countries, respectively [6].

The combustion of coal results in large volumes of solid coal combustion products (CCPs). Shahzad Baig and Yousaf [7] reported that for every 4 tons of burnt coal, 1 ton of CCPs is produced. The total volume of CCPs generated globally in 2016 was approximately 1122 million tons [8,9]. From 2011 to 2016, the worldwide production of CCPs increased by $44.4 \%$ (Table 1).

The main constituent of CCPs is fly ash. Yao et al. [11] reported that coal fly ash accounts for 5 to $20 \%$ of the mass of coal burned. In 2016, in European (EU-15) power plants, about 40 million tons of CCPs was generated [12]. The fly ash accounted for 63.8 wt. \% of CCPs (25.7 million tons) [12]. In 2016, 3.26 million tons of coal fly ash was produced in Poland. By 2018, its production had decreased to 2.43 million tons $[13,14]$. 

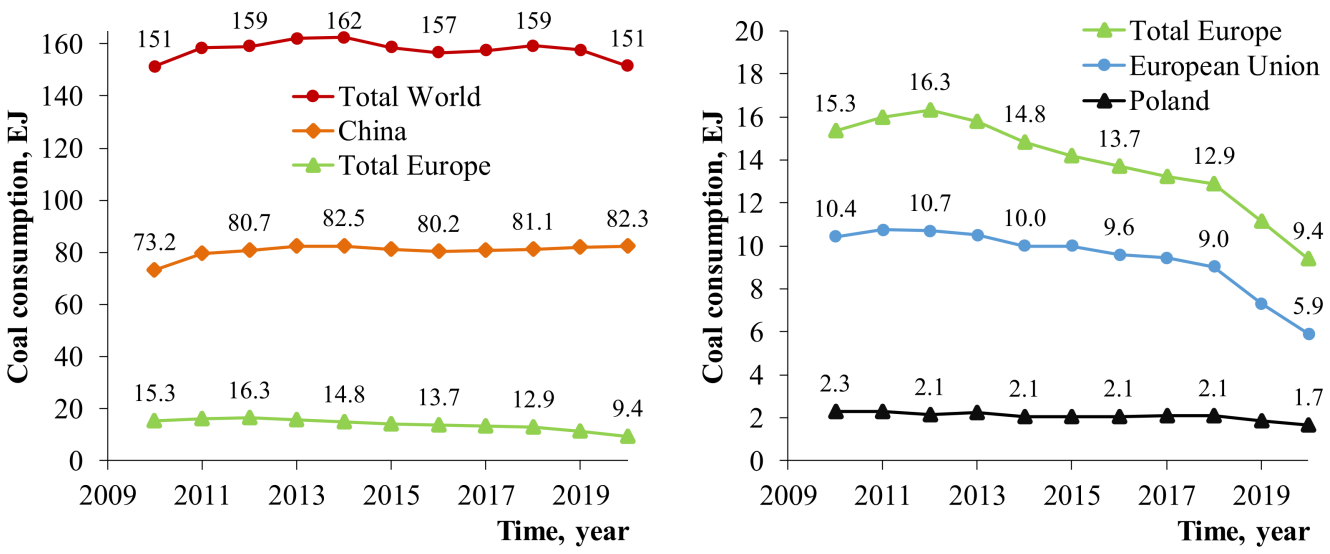

Figure 1. Coal consumption (data source comes from [5]).

Table 1. Production of CCPs by country/region [8-10].

\begin{tabular}{cccc}
\hline \multirow{2}{*}{ Country/Region } & \multicolumn{3}{c}{ CCPs Production, Mt } \\
\cline { 2 - 4 } & $\mathbf{2 0 1 1}$ & $\mathbf{2 0 1 5}$ & $\mathbf{2 0 1 6}$ \\
\hline Australia & 13.1 & 12.2 & 12.3 \\
Canada & 6.8 & 6.2 & 4.8 \\
China & 395 & 565 & 565 \\
Europe (EU) & 52.6 & 105 & 140 \\
India & 105 & 240 & 197 \\
Japan & 11.1 & 12.6 & 12.3 \\
Middle East and Africa & 32.2 & 33.3 & 32.2 \\
United States of America & 118 & 117 & 107.4 \\
Other Asia & 16.7 & 25.3 & 29.6 \\
Russian Federation & 26.6 & 26.6 & 21.3 \\
Total & 777.1 & 1143.2 & 1121.9 \\
\hline
\end{tabular}

In addition to CCPs, coal combustion contributes to the $\mathrm{CO}_{2}$ emissions. The amount of $\mathrm{CO}_{2}$ released depends on the type of coal burned [15]. In 2020, about $40 \%$ of $\mathrm{CO}_{2}$ emissions (13.98 billion tons) came from coal [16].

The properties of fly ash are closely related to the type of coal burned and the combustion process. Fly ash with pozzolanic properties is produced during the combustion of hard, bituminous, and sub-bituminous coal. In the case of combustion of lignite with a higher lime and sulfur content, ash with hydraulic properties is also produced [9,17]. Fly ash is characterized by a large specific surface area, which ranges from 250 to $500 \mathrm{~m}^{2} \mathrm{~kg}^{-1}$ [18-20]. It is mainly composed of $\mathrm{SiO}_{2}, \mathrm{Al}_{2} \mathrm{O}_{3}, \mathrm{Fe}_{2} \mathrm{O}_{3}$, and $\mathrm{CaO}$ [21]. Fly ash also contains elements such as $\mathrm{As}, \mathrm{B}, \mathrm{Cd}, \mathrm{Co}, \mathrm{Cr}, \mathrm{Hg}$, Pb, Se, and organic constituents, e.g., PAHs and PCBs, which are responsible for its toxicity $[18,22-24]$. The inappropriate storage and utilization of fly ash may pose a threat to human health and the environment. Particularly during the landfilling of fly ash, toxic constituents can be released into the environment as dust or leachates [11,25-27]. The highest potential to contaminate waterways and soil is coal ash ponds. These ponds are a type of landfill whose bottom is unlined. As a result, the coal ash constituents can leach into the ground and water. The mobility of trace metals contained in fly ash mainly depends on $\mathrm{pH}$. In turn, the $\mathrm{pH}$ of the water-fly ash system depends on the calcium content in fly ash. The alkalinity of fly ash may attenuate the mobility of $\mathrm{Cd}, \mathrm{Co}$, $\mathrm{Cu}, \mathrm{Hg}, \mathrm{Ni}, \mathrm{Pb}, \mathrm{Sn}$, and $\mathrm{Zn}$ and enhance the mobility of As, B, Cr, Mo, Sb, Se, V, and W [28].

Due to the chemical composition of fly ash, its agriculture use is also limited. The use of large amounts of fly ash may adversely affect the soil's biological and chemical properties [29-31].

Fly ash is a by-product commonly used in the production of building materials. Moreover, due to its sorption properties, it can be used as a removal material of metals and 
some organic contaminants. A review of the coal fly ash's properties and use was presented by Ahmaruzzaman [32] and Yao et al. [11].

For example, the chemical composition of fly ash from coal combustion enables its use in clinker production. Moreover, its use as a raw material allows the reduction in the sintering temperature, thus saving energy $[33,34]$. It is an important application due to energy costs and $\mathrm{CO}_{2}$ emissions. It is estimated that during the $1 \mathrm{~kg}$ of clinker production, $0.9-1 \mathrm{~kg}$ of $\mathrm{CO}_{2}$ is emitted [35]. In 2020, cement production was responsible for $4.7 \%$ of global $\mathrm{CO}_{2}$ emissions (1.63 billion tons) [16]. At that time, the global production of cement reached the level of 4.1 billion tons [36].

In the case of using fly ash in the production of cement, concrete, or low-cement binders, the pozzolanic properties are of particular importance. In Europe, the requirements for fly ash use in cement and concrete were described in the EN 450-1:2012 and EN 197-1:2011 [37,38] standard. The use of fly ash in concrete has a beneficial effect on its functional properties $[32,39]$. The addition of fly ash improves the workability of concrete. This is due to the spherical shape of its particles, which provides a lubricating effect in the concrete. The application of fly ash also improves the homogeneity of the concrete [17]. Moreover, fly ash, when used as a pozzolanic admixture, reacts with calcium hydroxide and forms a product similar in composition and properties to calcium silicate hydrate (C-S-H) $[40,41]$. In parallel, it follows a reduction in the pore interconnectivity of concrete, thus decreasing its permeability. The pozzolanic reactions are long-term processes; therefore, concrete containing fly ash may show a lower strength at a curing period of 28 days [39,42]. To improve the early-age strength, the development of fly ash concrete is possible by using an elevated curing temperature [43,44]. In addition to delaying binding and slowing down concrete hardening, a lower temperature rise due to less heat of hydration is observed $[39,40]$. The data on the fly ash pozzolanic properties and their reactions in concrete are presented in the ACI Committee report [39].

Another area of engineering application of fly ash is the production of cellular concrete [45-47], lightweight aggregates [48,49], ceramic tiles, and bricks [50]. The important sector that uses fly ash is mining. Fly ash is used for the back-filling of underground mining voids [51]. It is a typical method of fly ash recovery in Poland [52].

In 2016, in the EU-15 Member States, 31.5 wt.\% of the total fly ash generated was used as a cement raw material $(7.0 \%)$, as a constituent in blended cement $(7.2 \%)$, and as an addition for the production of concrete (17.3\%) [12]. Fly ash was also used in concrete blocks, reclamation, and for the infill of voids, mine shafts, and subsurface mine working [12,53]. In 2016, the EU-15 achieved a 94\% utilization rate of fly ash [12]. In Polish power plants using hard coal, silicate fly ash is usually obtained. This material is a valuable mineral resource for the building materials industry. In 2018, Poland achieved a $90.4 \%$ recovery rate of coal fly ash [14].

An interesting application of fly ash is its use as an adsorbent. Due to the specific properties of fly ash (large specific surface area and porosity), they can be used as a sorbent for selected organic compounds, e.g., VOCs. The European Union Directive 2004/42/CE defines VOCs as any organic compound having an initial boiling point less than or equal to $250{ }^{\circ} \mathrm{C}$ measured at a standard pressure of $101.3 \mathrm{kPa}$ [54]. The United States of America established a definition of VOCs based on photochemical reactivity. In accordance with the Code of Federal Regulations (40 CFR 51.100.), VOCs means any compound of carbon, excluding carbon monoxide, carbon dioxide, carbonic acid, metallic carbides or carbonates, and ammonium carbonate, which participates in atmospheric photochemical reaction [55]. The volatile organic compounds impose serious environmental problems such as global warming and ozone depletion [56]. One of the important classes of VOCs is aromatic hydrocarbons such as benzene, toluene, ethylbenzene, and xylenes (BTEX). Due to toxic, mutagenic, or carcinogenic (benzene, ethylbenzene) properties, the BTEX compounds are recognized as hazardous environmental pollutants [57]. The International Agency for Research on Cancer (IARC) classified benzene as carcinogenic to humans [58]. Benzene is used in the manufacture of styrene, phenols, cyclohexane, alkylbenzenes, and 
chlorobenzene. These substances may be used for the production of rubber, resins, nylon, or detergents. Benzene is also a natural constituent of gasoline. According to the Directive $2009 / 30 / E C$, its maximum content in petrol is limited to $1 \% v / v[59,60]$.

The BTEX compounds are emitted into the environment mainly from the chemical and petrochemical industry, motor vehicle transport, coal combustion, or painting [61-65]. BTEX compounds may diffuse into air and water. Furthermore, they penetrate the soil and cause a loss in soil functionality [66]. They can be adsorbed by organic matter occurring in soil, and also onto soil mineral surfaces.

One of the methods that can be used for the treatment of soil containing inorganic and organic (e.g., BTEX) contaminants is the technology of chemical solidification. In this process, the waste is blended with cement, fly ash, or their mixtures. This technique is widely used for the treatment of waste contaminated with heavy metals [67]. The inorganic contaminants show compatibility with cement [68]. As a result, the reduction in water content, increase in strength, and lowered mobility of contaminants are observed. Moreover, this method is used, e.g., in construction, to stabilize soils [69]. In the case of treating waste contaminated with organic compounds, the usefulness of this technique may be limited [70]. The organic compounds do not react with cement and fly ash. However, they can affect the efficiency of the cement and fly ash hydration process [68,71]. As a result, the products may show lower compressive strength [72,73].

Despite the application of cement and fly ash for utilization waste contaminated with organic, there is a lack of studies about the treatment of BTEX-contaminated soils, especially concerning their amount and characteristics of emissions during the treatment process. In the chemical solidification process, the BTEX contaminants can be physically trapped in a hardened binder or adsorbed by additional binding mixture constituents, e.g., activated carbon. For example, Butler et al. [74] demonstrated that the physical encapsulation of toluene is possible. The entrapped toluene formed vesicular, randomly placed structures in cement. To improve the BTEX encapsulation process, it is necessary to use the medium that will adsorb them and reduce their migration. The additives used for this purpose are fly ash, organoclays, or activated carbon.

The objectives of this study were (1) to investigate the possibility of using fly ash as a low-cost material for the treatment of benzene-contaminated soil (the fly ash was used as a mixture with cement); (2) the analysis of the variations in the benzene level emitted during the process; (3) the evaluation of physical properties of produced monoliths.

\section{Materials and Methods}

\subsection{Reagents for Preparation of Stabilizing Mixtures}

The following materials were used in the benzene-contaminated soil stabilization research described in this paper: Portland cement CEM I $45.5 \mathrm{R}$ and fly ash from coalburning. The cement used in the experiment was characterized by strength class 42.5 and high early strength (CEM I 42.5 R). The material met the requirements of the EN 197-1 standard [38]. A characteristic of PC is the production of a significant amount of heat during the setting. As a result, it can be used at low ambient temperatures.

The second component of the prepared stabilizing mixture was fly ash obtained from a Lower Silesian coal-fired power plant. The CFA contained around $53 \% \mathrm{SiO}_{2}, 24 \% \mathrm{Al}_{2} \mathrm{O}_{3}$, $6.4 \% \mathrm{Fe}_{2} \mathrm{O}_{3}, 3.4 \% \mathrm{CaO}, 2.8 \% \mathrm{MgO}$, and $0.5 \% \mathrm{SO}_{3}$. The important chemical parameter of fly ash is loss on ignition (LOI). It has to be noted that LOI does not represent the unburned carbon in ashes, because of the presence of several other compounds that also decompose on heating. The high content of unburned carbon increases the water demand of the fly ash. As a result, the products based on fly ash with high unburned coal content show low strength. The loss on ignition of used CFA was 3.9\%.

\subsection{Soil}

The research was carried out on soil from rural areas in Lower Silesia (Poland). The basic material properties, such as humidity and organic matter content, were $3.41 \%$ (by 
weight) and $1.97 \%$ of dry matter, respectively. The particle-size distribution analysis showed that the soil was noncohesive (Figure 2). The sand fraction content was greater than $90 \%$ (by weight). Sieve analysis also showed the presence of dust particles with grains below $0.063 \mathrm{~mm}$ in diameter (ca. 5.3\%). The bulk density of soil amounted to $1.21 \mathrm{~g} \mathrm{~mL}^{-1}$. The estimated particle diameters D10, D30, and D60 were, respectively, $0.12 \mathrm{~mm}, 0.30 \mathrm{~mm}$, and $0.57 \mathrm{~mm}$. Based on substitutive diameters, the uniformity coefficient $\left(C_{U}=4.91\right)(1)$ and coefficient of gradation $\left(\mathrm{C}_{\mathrm{C}}=1.34\right)(2)$ were calculated.

$$
\begin{gathered}
\mathrm{C}_{\mathrm{U}}=\mathrm{D} 60 / \mathrm{D} 10, \\
\mathrm{C}_{\mathrm{C}}=\mathrm{D} 30^{2} /(\mathrm{D} 10 \cdot \mathrm{D} 60),
\end{gathered}
$$

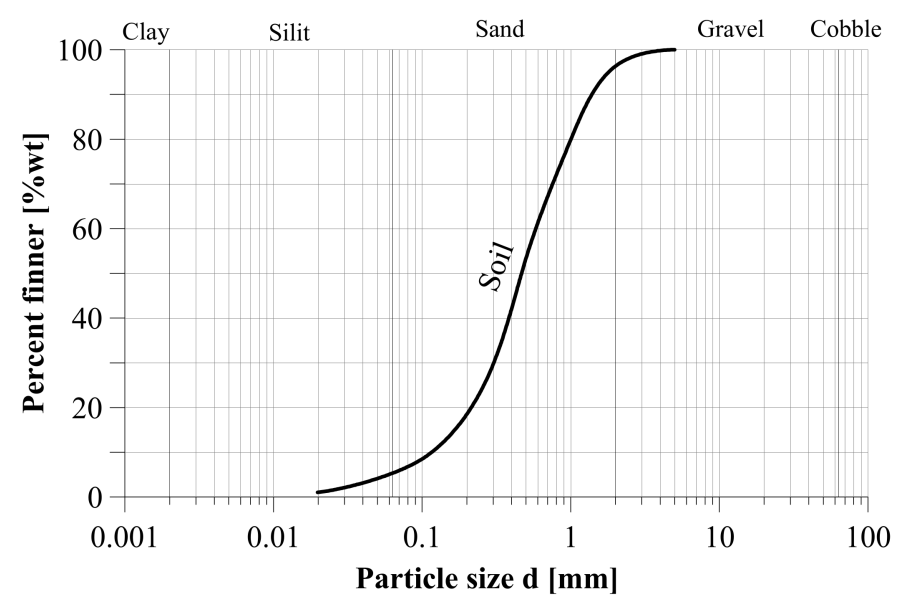

Figure 2. Grain size distribution curve of used soil.

According to the applied procedure, $200 \mathrm{~g}$ samples of raw soil were contaminated with $0.5 \mathrm{~mL}$ of benzene and mixed for $2 \mathrm{~min}$ using a Heidolph Reax 20/8 shaker. Soil samples prepared in this way were stored at $7^{\circ} \mathrm{C}$ for $24 \mathrm{~h}$ and then treated with the PC-CFA mixture.

\subsection{Methodology of Contaminated Soil Treatment Process}

The benzene-spiked soil samples (S) were processed with the PC-CFA mixture. The content of PC and CFA in the mixture was, respectively, 70\% w/w and 30\%. In turn, the dose of the PC-CFA mixture was $40 \%, 60 \%$, and $80 \%$ of the soil mass.

The homogenization of all components (S+PC-CFA) was performed for $5 \mathrm{~min}$ in a Tecnotest B205/X5 mixer. Monoliths with soil were obtained by the further addition of water for initiation of the cement hydration process. Homogenization of the wet mix also took $5 \mathrm{~min}$. The obtained cement-soil mixture was molded and hardened for 28 days.

Temperature conditions have a significant influence on the emission of VOCs. For this reason, the temperature and relative humidity were monitored throughout the process. The values were, respectively, $20 \pm 0.5^{\circ} \mathrm{C}$ and $25 \pm 3 \% \mathrm{RH}$. Measurements were made using the Hanna Instruments HI 9564 Thermohigrometer.

During the process, the concentration of benzene in the reactor was monitored. The amount of benzene was measured using a Micro FID flame-ionization detector (Photovac). The gas samples were transported to the detector through PTFE tubing. Moreover, a dust filter was installed at the inlet to the PTFE tubing. The FID was calibrated against methane. The benzene concentration was calculated based on reaction coefficients that may be applied in the situation of a single contaminant in the atmosphere. To evaluate the repeatability and stability of the process, all samples were tested three times.

The effectiveness of using the PC-CFA mixture as a stabilizing material for benzenecontaminated soil was assessed based on a comparative analysis of concentrations in the phase of homogenization of dry components and reference samples $(S+0(x))$. In the case of zero samples, the PC-CFA mixture was not added. Their composition included only $200 \mathrm{~g}$ 
of raw soil contaminated with $0.5 \mathrm{~mL}$ of benzene. The parameters of homogenization of the reference samples were the same as those of the samples with the PC-CFA mixture.

\subsection{Compressive Strength}

One of the parameters tested to determine the effectiveness of the chemical solidification process was compressive strength. The prepared soil-cement-ash mixtures were placed in cylindrical molds and compacted. After 3 days of maturation, samples were de-molded and cured for another 25 days. The strength tests of the monoliths with benzenecontaminated soil (with diameter and height $=50 \pm 3 \mathrm{~mm}$ ) were determined after 28 days of hardening. Each of the prepared soil-cement-ash mixtures was tested three times.

\subsection{Capillary Rise Height of Water}

Capillary rise height was evaluated during the first phase of determining mass absorbability. The experiment was carried out to illustrate the behavior of soil-cement-ash monoliths deposited in landfills (this especially concerns bottom parts of monoliths exposed to long-term contact with eluates). To determine the speed of water imbibition, dried soil composites were submerged in water to $\frac{1}{4}$ of their height. During the test, water was absorbed mainly through cylindrical surfaces of monoliths. The height of water imbibition was measured after 15, 30, and $60 \mathrm{~min}$.

\subsection{Water Absorption}

Mass water absorption is the ratio of the mass of water absorbed through the monolith to the weight of the dry monolith. The water absorption capacity test of monoliths was carried out by the procedure described in the PN-B-04101 standard [75]. According to the test method, samples were stepwise-immersed in water. Such a treatment is to avoid the entrapment of air inside the monolith. In the first step, dried monoliths were placed in a vessel and flooded with water to $\frac{1}{4}$ of their height. After $2 \mathrm{~h}$, the water level was increased to $\frac{1}{2}$ of their height, and after another $3 \mathrm{~h}$, up to $\frac{3}{4}$. The samples were left in such an immersion for $19 \mathrm{~h}$, after which they were completely flooded with water. Finally, the upper surface of the samples was $2 \mathrm{~cm}$ below the water level. Such prepared samples were left for $24 \mathrm{~h}$. Next, samples were taken from the water and weighed (with the accuracy of $\pm 0.01 \mathrm{~g}$ ) in $24 \mathrm{~h}$ intervals. The weighing was repeated until a constant weight of the monolith was achieved.

Water absorption $\left(\mathrm{W}_{\mathrm{A}}\right)$ was calculated according to Equation (3):

$$
\mathrm{W}_{\mathrm{A}}=\left[\left(\mathrm{W}_{\mathrm{w}}-\mathrm{W}_{\mathrm{d}}\right) / \mathrm{W}_{\mathrm{d}}\right] \cdot 100 \%,
$$

where: $W_{\mathrm{w}}$ is the mass of the monolith saturated with water and $\mathrm{W}_{\mathrm{d}}$ is the mass of a monolith in the dry state.

\section{Results and Discussion}

\subsection{Efficacy of the Cement-Fly Ash Matrix}

Data on the benzene concentration changes in the mixer during the process are presented graphically in Figure 3.

The FID measurements showed a sudden increase in benzene concentration at the beginning of the mechanical mixing of components. Concentrations of benzene recorded by the FID were in the following ranges: (i) $<0.1-2596 \mathrm{ppm} \mathrm{C}_{6} \mathrm{H}_{6}$ for zero samples, (ii) $1.8-2280$ ppm $\mathrm{C}_{6} \mathrm{H}_{6}$ for series of samples stabilized with PC-CFA mixture in an amount of $40 \%$ of

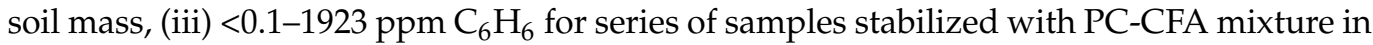
an amount of $60 \%$ of soil mass, and (iv) $0.3-1486 \mathrm{ppm} \mathrm{C}_{6} \mathrm{H}_{6}$ for series of samples stabilized with PC-CFA mixture in an amount of $80 \%$ of soil mass. The highest concentrations were measured for reference samples ( $\mathrm{S}+0(\mathrm{x})$ samples). For all samples, the maximum concentration of benzene was recorded between the 30th and the 45th seconds of the process (Figure 3). The research confirmed that the risk of releasing significant amounts of 
gaseous contaminants occurs mainly during the homogenization of dry components (soil and PC-CFA mixture) $[76,77]$.

The introduction of the PC-CFA mixture caused a decrease in maximum momentary benzene concentration. The level of the decrease was in the range of (i) $12-19 \%$ for S+(PC-CFA) 40 samples, (ii) 24-35\% for S+(PC-CFA)60 samples, and (iii) $40-46 \%$ for $\mathrm{S}+(\mathrm{PC}-\mathrm{CFA}) 80$ samples (Table 2). Nevertheless, the introduction of fine-grain-size materials (PC and CFA) did not influence the dynamics of the analyzed solvent release. In each trial, the emission of $90 \%$ of the total quantity of benzene released during the process occurred between 100 and $150 \mathrm{~s}$ of the homogenization phase. The properties of the solvent and used removal material have a significant influence on gaseous contaminant emission characteristics [77]. The main mechanisms of the discussed benzene removal technology are adsorption and physical encapsulation processes. Benzene is a nonpolar compound, which is slightly soluble in water [78]. In the soil environment, it can be adsorbed on soil particles or fill soil pores as a gas [79]. One of the factors determining its adsorption in the liquid-solid interface is soil organic matter content [80]. Lake et al. [81] reported that benzene interacts with hydrophobic groups of humic acid. The used soil was characterized by low organic matter content, which could affect the adsorption of benzene. Another factor that influences the adsorption efficacy is soil particle size. Sun et al. [82] showed that as the particle size decreases, the adsorption efficiency of benzene increases. It is a result of the increase in the specific surface area of the soil particles. In comparison to silty soils or clay soils, sandy soils characterize the lower specific surface area. The sand fraction content in the used soil was greater than $90 \%$ (by weight). Another factor that affected benzene release is the speed of mixing soil with stabilizing-binding components. The applied rotary speed was $140 \mathrm{rpm}$. During the mixing, the particles of contaminated soil violently collide. As a result, the increase in the processes of desorption and volatilization of vapors collected in soil pores is observed [82]. Thus, when treating benzene-spiked soil, lowering the mixing speed of dry components may have a positive impact on the initial volume of gaseous pollutants released.
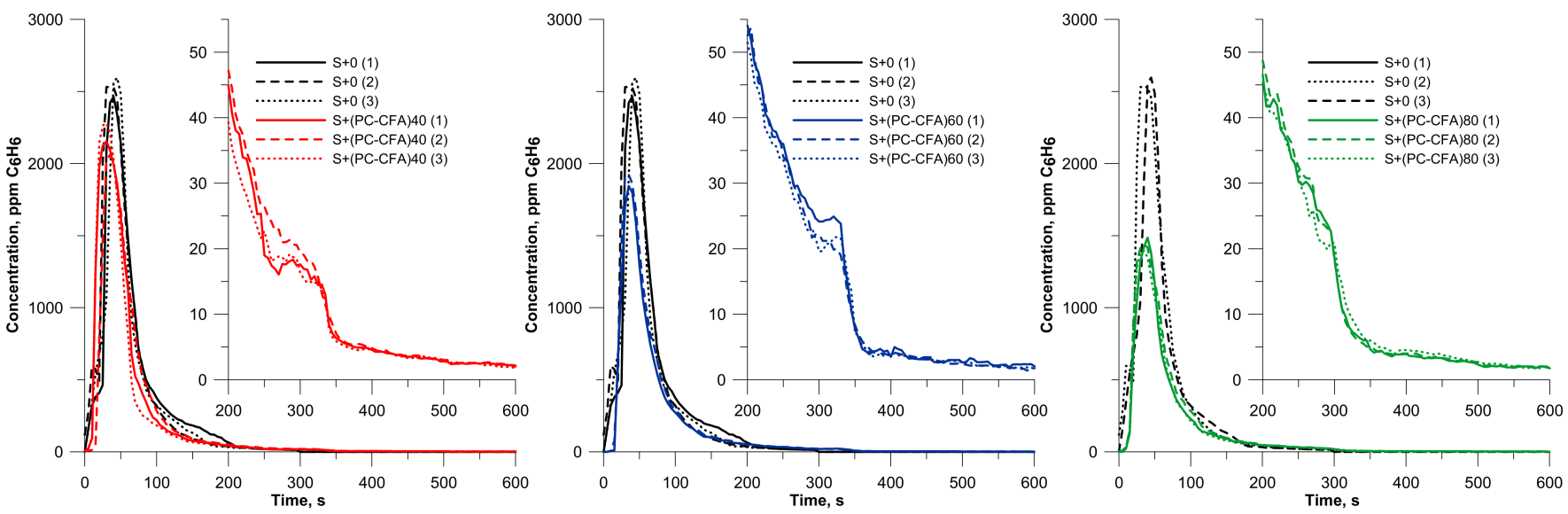

Figure 3. Comparison of benzene emissions during the chemical solidification process of soil using cement-fly ash mixture. Code of the sample: S—soil, PC-CFA-Portland cement-coal fly ash mixture, 40/60/80-PC-CFA mixture dose expressed as a percent of soil mass, (1)/(2)/(3)—sample number.

An important moment of the chemical solidification process is the hydration stage. The required amount of water depends on the quantity of cement and immobilizing additives, their properties, as well as the water demand of the processed waste. When treating soil contaminated with VOCs, limiting their release during the homogenization stage may result in a higher concentration of pollutants in the process air during the hydration stage. Donaldson et al. [83] reported that the introduction of water accelerates the removal from the soil of hydrocarbons found in gasoline. This phenomenon was observed in research of the neutralization of soils contaminated with ethylbenzene or xylenes [76,77]. Water fills 
the pores of the soil and blocks minerals' specific surface area. As a result, a lowering in the adsorption capacity of the organic vapors is observed [84]. In the research, water was added in the 300th second of the dry components' mixing. The temporary stabilization or a slight increase in benzene concentration was observed for samples treated with the PC-CFA mixture in amounts of 40 and $60 \%$ of soil mass (S+(PC-CFA)40 and S+(PC-CFA)60, respectively) (Figure 3).

Table 2. PC-CFA mixture efficacy.

\begin{tabular}{|c|c|c|c|c|c|c|}
\hline \multirow[b]{2}{*}{ Series } & \multirow[b]{2}{*}{ Sample } & \multirow{2}{*}{$\begin{array}{l}\text { Maximum Momentary } \\
\text { Concentration, ppm } \mathrm{C}_{6} \mathrm{H}_{6}\end{array}$} & \multicolumn{3}{|c|}{ Average Concentration, ppm $\mathrm{C}_{6} \mathrm{H}_{6}$} & \multirow{2}{*}{$\begin{array}{c}\text { Immobilization Efficacy, \% } \\
\text { Homogenization Stage }\end{array}$} \\
\hline & & & $\begin{array}{l}\text { Homogenization } \\
\text { Stage }\end{array}$ & $\begin{array}{l}\text { Hydration } \\
\text { Stage }\end{array}$ & Process & \\
\hline \multirow{4}{*}{ (1) } & $\mathrm{S}+0$ & 2463 & 430 & - & - & - \\
\hline & $\mathrm{S}+(\mathrm{PC}-\mathrm{CFA}) 40$ & 2154 & 386 & 5.20 & 194 & 10 \\
\hline & $\mathrm{S}+(\mathrm{PC}-\mathrm{CFA}) 60$ & 1844 & 309 & 5.72 & 156 & 28 \\
\hline & $\mathrm{S}+(\mathrm{PC}-\mathrm{CFA}) 80$ & 1486 & 262 & 3.93 & 132 & 39 \\
\hline \multirow{4}{*}{$(2)$} & $S+0$ & 2531 & 450 & - & - & - \\
\hline & $\mathrm{S}+(\mathrm{PC}-\mathrm{CFA}) 40$ & 2060 & 363 & 5.53 & 183 & 19 \\
\hline & $\mathrm{S}+(\mathrm{PC}-\mathrm{CFA}) 60$ & 1923 & 337 & 5.61 & 170 & 25 \\
\hline & $\mathrm{S}+(\mathrm{PC}-\mathrm{CFA}) 80$ & 1438 & 289 & 3.98 & 145 & 36 \\
\hline \multirow{4}{*}{ (3) } & $S+0$ & 2596 & 397 & - & - & - \\
\hline & $\mathrm{S}+(\mathrm{PC}-\mathrm{CFA}) 40$ & 2280 & 364 & 4.99 & 183 & 8.3 \\
\hline & $\mathrm{S}+(\mathrm{PC}-\mathrm{CFA}) 60$ & 1675 & 308 & 6.23 & 156 & 22 \\
\hline & S+(PC-CFA) 80 & 1395 & 262 & 4.58 & 132 & 34 \\
\hline
\end{tabular}

The continuous measurements showed that the most neuralgic stage of the benzenecontaminated soil chemical solidification process is the homogenization phase. The average concentration, as well as the total amount of emitted benzene in the first stage of the process, was several dozen times higher than in the hydration stage (Table 2). Nevertheless, the introduction of the PC-CFA mixture lowered the averaged benzene concentration in the reactor. A decrease in the concentration increased the PC-CFA dose.

The highest reduction in average benzene concentration in the homogenization stage (in the range 34-39\%) was recorded for samples S+(PC-CFA)80. In the case of samples S+(PC-CFA)60, the benzene immobilization efficacy was in the range of 22-28\%. The lowest effectiveness (from 8 to 19\%) was observed for composites S+(PC-CFA)40 (Table 2). The main factor determining the effectiveness of the analyzed process is the unburned carbon content (UBC). The UBC mainly depends on fly ash dose. In turn, the carbon content in fly ash depends on the type of coal and its combustion conditions $[85,86]$ Thus, the presented results are adequate only for similar process parameters (temperature, humidity, and soil and fly ash properties). An important element of the used treatment process is the interaction of cement with fly ash. During the hydration process, cement paste may physically block the internal fly ash pores [81]. As a result, its adsorption capacity may be limited. One of the factors that may improve the benzene adsorption may be the introduction of fly ash before cement addition. As a result, benzene associated with fly ash can be coated with hydrated cement [81]. In this way, its volatilization can be reduced.

The greatest problem in monitoring benzene emission during the chemical solidification process was high concentrations of particulate pollutants in the air inside the reactor. This was especially true for the stage of homogenizing binding components with soil. In the case of continuous measurements, mineral particles were eliminated in a filter mounted before a combustion chamber. Nevertheless, the limitation of process airflow by solid particles accumulated on the filter and in ducts might affect the quality of continuous measurements in the phase of hydration. In the conference paper [87], the authors compared the results of continuous measurements of benzene concentration in the reactor and its mass adsorbed on activated carbon. 


\subsection{Compressive Strength}

Compressive strength is one of the parameters determining the efficiency of the chemical solidification process. To be suitable for deposition and transport, monoliths must be characterized by some minimum value of stress. Knowledge of the stress that does not change monoliths' shape and structure enables, among others, the determination of the maximum thickness of waste in the landfill. Unfortunately, no normative regulations according to the compressive strength of solidified waste are currently in force in Poland.

The compressive strength tests of solidified benzene-contaminated soil were performed after 28 days of hardening. Measurements were taken in three replications. The impact of the applied PC-CFA mixture dose on the strength of the monoliths with benzenecontaminated soil is illustrated in Figure 4.

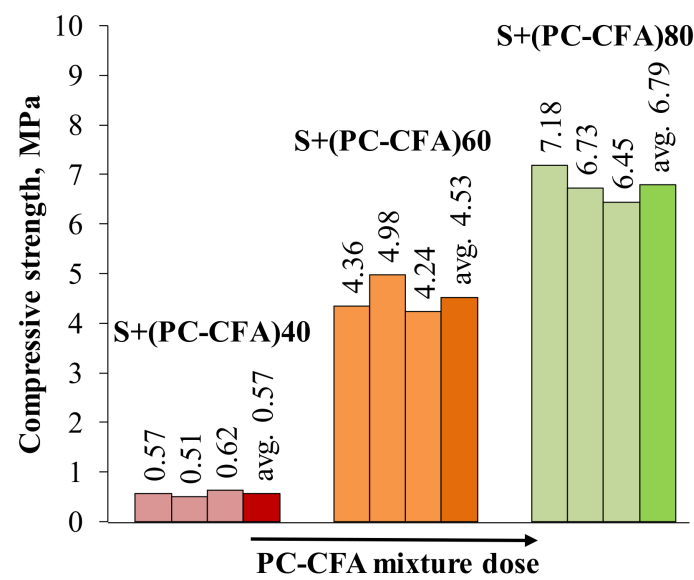

Figure 4. Dependence of the compressive strength of the monoliths with benzene-contaminated soil on PC-CFA mixture dose.

The average compressive strength $(f c)$ of monoliths S+(PC-CFA)40, S+(PC-CFA)60, and S+(PC-CFA) 80 was $0.57 \mathrm{MPa}, 4.53 \mathrm{MPa}$, and $6.79 \mathrm{MPa}$, respectively (with water-binder ratio $0.77,0.64$, and 0.54 , respectively). The worst mechanical parameters (avg. $f c=0.57 \mathrm{MPa}$ ) were found in samples solidified with the binding mixture in an amount of $40 \%$ of soil mass. Such a level of compressive strength corresponds to the characteristics of poor cement-lime mortar. Increasing the stabilizing-binding mixture dose from $40 \%$ to $80 \%$ of soil mass resulted in an almost twelvefold increase in strength value. The use of cementfly ash mixtures is beneficial from a cost perspective and organic contaminants sorption. Nevertheless, it is known that cement-fly ash mixtures show a lower early compressive strength compared to the samples based on cement without fly ash. The fly ash reacts with cement hydrates (portlandite) and forms extra C-S-H gel that helps to achieve a more compact structure. Nevertheless, the rate of pozzolanic reaction in 28 days is slow. At a curing period of 28 days, the cement-fly ash mixtures are characterized by a higher percentage of voids. The strength is particularly influenced by the presence of voids bigger than $20 \mathrm{~nm}$ [88]. As a result, the strength of monoliths mainly depends on the amount of introduced cement. In addition, the presence of mineral particles smaller than $0.063 \mathrm{~mm}$ may be particularly important. This fraction increases water absorbability and sticks agglomerate grains, thus diminishing the zone of contact with pure agglomerate. The impact of introducing soil spiked with benzene should also be considered. Ezeldin et al. [89] showed that replacing fine aggregate in concrete with benzene-contaminated soils causes a decrease in mechanical properties of concrete, especially when silty sand was used. However, the pozzolanic reaction improves to a limited extent the strength of monoliths based on cement blended with fly ash with an increase in the curing time [90,91]. 


\subsection{Capillary Rise Height of Water}

In addition to a high degree of encapsulation of processed soil and sufficiently high compressive strength, monoliths must be characterized by low permeability and low liquid penetration. Both high mass absorbability and capillary pull-up have a destructive effect on the durability of products of the chemical solidification process. The properties mentioned are especially essential in the case of depositing solidified waste in landfills (this especially concerns bottom parts of waste exposed to long-term contact with eluates). In addition, the low tightness of monoliths may cause the secondary emission of organic pollutants' built-in matrices of hydraulic binders. Thus, the formation of monoliths characterized by high tightness is essential.

Soil-cement-ash monoliths elaborated in the experiment were characterized by the mass ratio of water to PC-CFA mixture from 0.54 for sample S+(PC-CFA) 80 to 0.77 for sample S+(PC-CFA)40. The height of water imbibition was measured after 15, 30, and 60 min of contact with water. Analysis of capillary action after 28 days of maturation showed that all monoliths were characterized by the high content of capillary pores. In the case of sample S+(PC-CFA)40, water reached $3.5 \mathrm{~cm}$ high in only $60 \mathrm{~min}$ (Figure 5). Increasing the dose of the PC-CFA mixture to $80 \%$ of soil mass (S+(PC-CFA) 80 ) resulted in a reduction in capillary rise height to $1.3 \mathrm{~cm}$ (after $60 \mathrm{~min}$ of contact with water). Long-term moistness of the solidified waste with liquids of high salinity may lead to the structural destruction of cement slurry. The high permeability of prepared monoliths might be a result of the formation of a higher percentage of voids in mixtures containing fly ash (after 28 days of maturation) and a poor bonding of benzene-contaminated soil with hydrated cement paste. Generally, the pore structure of cement paste is closely related to the water-cement ratio and hydration period [92].

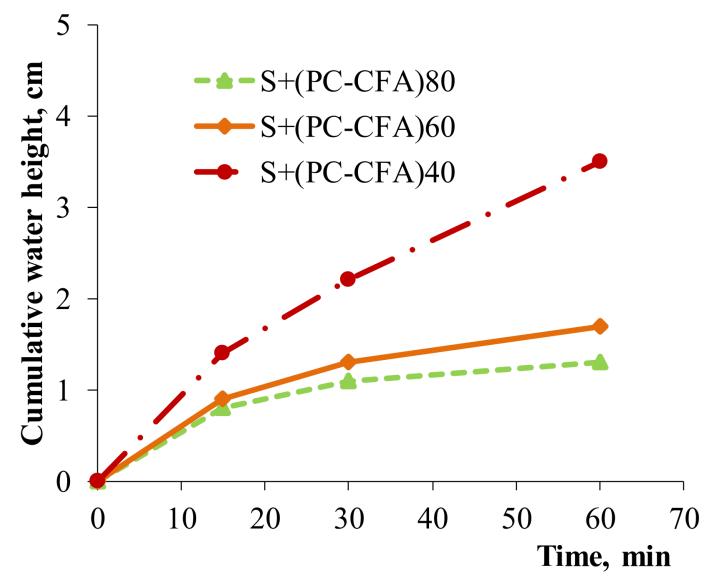

Figure 5. Cumulative height of water absorbed by capillarity of the solidified samples.

\subsection{Water Absorption}

Data on the water absorption capacity of monoliths with benzene-contaminated soil are shown in Figure 6. The test showed a decrease in the water absorption capacity of the samples with an increase in the proportion of the PC-CFA mixture. All the tested specimens based on the PC-CFA mixture exhibited high water absorption capacities by $15-22 \% \mathrm{dm}$. Samples solidified with the mixture in amounts of $60 \%$ and $80 \%$ of soil mass (S+(PC-CFA) 60 and S+(PC-CFA) 80 , respectively) were characterized by similar values of water absorption, at the level of about 15-16\% dm (Figure 6).

The highest value was presented by sample S+(PC-CFA) 40 , which was $22 \% \mathrm{dm}$. Moreover, the monolith S+(PC-CFA) 40 was unstable upon water immersion. Degradation of the sample S+(PC-CFA) 40 was observed on the 6th day of its immersion in water. High water absorption creates a significant risk in the case of exposure to sub-zero temperatures. An increased volume of water in pores during a phase transition weakens the structure of monoliths mainly through internal crack growth [93]. 


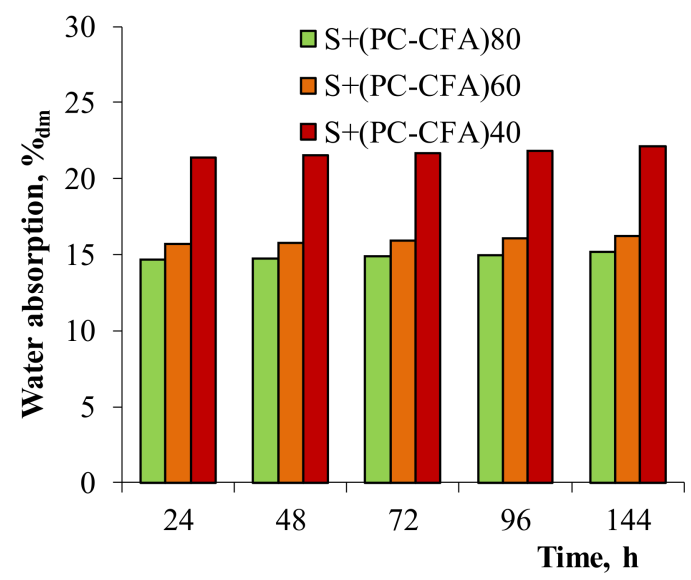

Figure 6. Water absorption capacity of solidified specimens.

\section{Conclusions}

The evaluated data led to the following conclusions:

- Continuous measurements of benzene concentrations showed that its emission had a very dynamic course. In all tests, the emission of $98 \%$ of the total amount of benzene released in the chemical solidification process already occurred in the homogenization phase.

- Experiments confirmed the possibility of limited use of the PC-CFA mixture as a low-cost material to remove benzene. The results showed that the PC-CFA mixture could limit the volume of benzene released during the process. The introduction of the cement-ash mixture in an amount of $80 \%$ of contaminated soil (by weight) reduced benzene emission in the first phase of the process by avg. $36 \%$.

- The research did not show any significant influence of the amount of the stabilizingbinding mixture on emission dynamics of the analyzed solvent.

- The adsorption properties of the fly ash mainly depend on unburned carbon content (UBC). The UBC depends on the type of coal and its combustion conditions. Thus, the presented results are adequate only for the used fly ash type and process conditions (the proven efficiency of the PC-CFA mix applies to the following conditions: humidity of $25 \% \mathrm{RH}$ and temperature of $20^{\circ} \mathrm{C}$ ).

- Mechanical tests confirmed a strict relationship between the value of mechanical compressive strength and the dose of binding materials. The highest strength (more than $6 \mathrm{MPa}$ ) was observed in samples that were treated with the PC-CFA mixture in an amount of $80 \%$ of the mass of processed soil. The possible explanation of low compressive strength values may be a poor bonding of benzene-contaminated soil with hydrated cement paste or slow pozzolanic reaction of fly ash.

- The capillary imbibition of water after 28 days of maturation showed that all monoliths were characterized by the high content of capillary pores.

- The water sorption capacity of the spiked soil sample solidified with the PC-CFA mixture in an amount of $40 \%$ of soil mass was $22 \% \mathrm{dm}$. The monolith S+(PC-CFA) 40 was unstable, and its degradation was observed on the 6th day of its immersion in water.

- The increase in the dose of the ash-cement mixture resulted in a reduction in capillary imbibition of water and its absorption by immersion.

In conclusion, the cement-ash mixture can be considered a cheap and effective material for the treatment of soils containing low levels of benzene. The analyzed process can be used in developing countries without infrastructure for hazardous waste treatment. Nevertheless, due to the parameters that affect the effectiveness of benzene entrapping (e.g., temperature conditions, and soil and fly ash properties), the use of the PC-CFA mixture may be limited. 


\begin{abstract}
Author Contributions: Conceptualization, T.M. and K.B.; methodology, K.B. and T.M.; investigation, K.B. and I.P.; data analysis, K.B. and I.P.; writing—original draft preparation, K.B., I.P. and T.M.; writing-review and editing, K.B., I.P. and T.M. All authors have read and agreed to the published version of the manuscript.
\end{abstract}

Funding: This research received no external funding.

Institutional Review Board Statement: Not applicable.

Informed Consent Statement: Not applicable.

Data Availability Statement: Not applicable.

Conflicts of Interest: The authors declare no conflict of interest.

\title{
References
}

1. International Energy Agency. Coal 2020. Analysis and Forecast to 2015; IEA: Paris, France, 2020. Available online: https: / / www.iea.org/reports/coal-2020 (accessed on 7 January 2022).

2. International Energy Agency. China Has a Clear Pathway to Build a More Sustainable, Secure and Inclusive Energy FutureNews-IEA. Available online: https: / / www.iea.org/news/china-has-a-clear-pathway-to-build-a-more-sustainable-secure-andinclusive-energy-future (accessed on 7 January 2022).

3. Enerdata. Global Energy Statistical Yearbook 2019. 2019. Available online: https://yearbook.enerdata.net/coal-lignite/coalworld-consumption-data.html (accessed on 9 July 2020).

4. Ministerstwo Aktywów Państwowych. Krajowy Plan na Rzecz Energii i Klimatu na Lata 2021-2030 (Ministry of State Assets National Energy and Climate Plan for the Years 2021-2030). 2019. Available online: https://www.gov.pl/web/klimat/krajowyplan-na-rzecz-energii-i-klimatu (accessed on 9 July 2020).

5. BP. Statistical Review of World Energy. 2021. Available online: https://www.bp.com/en/global/corporate/energy-economics/ statistical-review-of-world-energy.html (accessed on 7 January 2022).

6. Enerdata. Global Energy Trends-2021 Edition. 2021. Available online: https://www.enerdata.net/publications/reportspresentations/world-energy-trends.html (accessed on 7 January 2022).

7. Shahzad Baig, K.; Yousaf, M. Coal Fired Power Plants: Emission Problems and Controlling Techniques. J. Earth Sci. Clim. Chang. 2017, 8, 404. [CrossRef]

8. World Wide Coal Combustion Network. Member Information 2018/2019 via: Harris et al. 2020. Available online: https: //wwccpn.com/ (accessed on 7 January 2022).

9. Harris, D.; Heidrich, C.; Feuerborn, J. Global Aspects on Coal Combustion Products. VGB PowerTech 2020, 10, 25-33. Available online: https:/ / www.vgb.org/vgbmultimedia/PT202010HARRIS-p-16422.pdf (accessed on 3 April 2021).

10. Heidrich, C.; Feuerborn, H.J. Coal Combustion Products: Global Operating Environment, WWCCPN, World of Coal Ash. 2017. Available online: https://www.adaa.asn.au/blog/2017/06/wwccpn-the-global-operating-environment (accessed on 3 April 2021).

11. Yao, Z.T.; Ji, X.S.; Sarker, P.K.; Tang, J.H.; Ge, L.Q.; Xia, M.S.; Xi, Y.Q. A comprehensive review on the applications of coal fly ash. Earth-Sci. Rev. 2015, 141, 105-121. [CrossRef]

12. European Coal Combustion Products Association. Statistics. 2016. Available online: http://www.ecoba.com/ecobaccpprod.html (accessed on 3 April 2021).

13. Statistics Poland. Environment 2017. Warsaw. 2017. Available online: https://stat.gov.pl/en/topics/environment-energy/ environment/environment-2017,1,9.html (accessed on 9 November 2021).

14. Statistics Poland. Environment 2019. Warsaw. 2019. Available online: https://stat.gov.pl/en/topics/environment-energy/ environment/environment-2019,1,11.html (accessed on 9 November 2021).

15. U.S. Energy Information Administration. How Much Carbon Dioxide Is Produced When Different Fuels Are Burned? Available online: https: / / www.eia.gov/tools / faqs / faq.php?id=73\&t=11 (accessed on 7 January 2022).

16. Ritchie, H.; Roser, M. $\mathrm{CO}_{2}$ and Greenhouse Gas Emissions. Published Online at OurWorldInData.org. 2020. Available online: https:/ / ourworldindata.org/co2-and-other-greenhouse-gas-emissions (accessed on 7 January 2022).

17. Thomas, M.D.A. Optimizing the Use of Fly Ash in Concrete; PCA Report IS548; Portland Cement Association: Skokie, IL, USA, 2007.

18. Shaheen, M.S.; Hooda, P.S.; Tsadilas, C.D. Opportunities and challenges in the use of coal fly ash for soil improvements-A review. J. Environ. Manag. 2014, 145, 249-267. [CrossRef]

19. Wesche, K. (Ed.) Fly Ash in Concrete: Properties and Performance; CRC Press: London, UK, 1991.

20. Arvaniti, E.C.; Juenger, M.C.G.; Bernal, S.A.; Duchesne, J.; Courard, L.; Leroy, S.; De Belie, N.; Provis, J.L.; Klemm, A. Determination of particle size, surface area, and shape of supplementary cementitious materials by different techniques. Mater. Struct. 2015, 48, 3687-3701. [CrossRef]

21. Hosseini Asl, S.M.; Javadian, H.; Khavarpour, M.; Belviso, C.; Taghavi, M.; Maghsudi, M. Porous adsorbents derived from coal fly ash as cost-effective and environmentally-friendly sources of aluminosilicate for sequestration of aqueous and gaseous pollutants: A review. J. Clean. Prod. 2019, 208, 1131-1147. [CrossRef] 
22. Basu, M.; Pande, M.; Bhadoria, P.B.S.; Mahapatra, S.C. Potential fly ash utilization in agriculture: A global review. Prog. Nat. Sci. 2009, 19, 1173-1186. [CrossRef]

23. Sahu, S.K.; Bhangare, R.C.; Ajmal, P.Y.; Sharma, S.; Pandit, G.G.; Puranik, V.D. Characterization and quantification of persistent organic pollutants in fly ash from coal fueled thermal power stations in India. Microchem. J. 2009, 92, 92-96. [CrossRef]

24. Zierold, K.M.; Odoh, C. A review on fly ash from coal-fired power plants: Chemical composition, regulations, and health evidence. Rev. Environ. Health 2020, 35, 401-418. [CrossRef] [PubMed]

25. Rowe, C.L.; Hopkins, W.A.; Congdon, J.D. Ecotoxicological implications of aquatic disposal of coal combustion residues in the United States: A review. Environ. Monit. Assess. 2002, 80, 207-276. [CrossRef]

26. United States Environmental Protection Agency. Hazardous and solid waste management system; identification and listing of special wastes; disposal of coal combustion residuals from electric utilities; proposed rule (Codified at 40 CFR Parts 257, 261, 264, 265, 268, 271 and 302). Fed. Regist. 2010, 75, 35127-35264.

27. Singh, R.K.; Gupta, N.C.; Guha, B.K. Fly Ash Disposal in Ash Ponds: A Threat to Ground Water Contamination. J. Inst. Eng. India Ser. A 2016, 97, 255-260. [CrossRef]

28. Izquierdo, M.; Querol, X. Leaching behaviour of elements from coal combustion fly ash: An overview. Int. J. Coal Geol. 2012, 94, 54-66. [CrossRef]

29. Nayak, A.K.; Raja, R.; Rao, K.S.; Shukla, A.K.; Mohanty, S.; Shahid, M.; Swain, C.K. Effect of fly ash application on soil microbial response and heavy metal accumulation in soil and rice plant. Ecotoxicol. Environ. Saf. 2014, 114, 257-262. [CrossRef] [PubMed]

30. Singh, P.K.; Tripathi, P.; Dwivedi, S.; Awasthi, S.; Shri, M.; Chakrabarty, D.; Tripathi, R.D. Fly-ash augmented soil enhances heavy metal accumulation and phytotoxicity in rice (Oryza sativa L.); A concern for fly-ash amendments in agriculture sector. Plant Growth Regul. 2016, 78, 21-30. [CrossRef]

31. Jambhulkar, H.P.; Shaikh, S.M.S.; Kumar, M.S. Fly ash toxicity, emerging issues and possible implications for its exploitation in agriculture; Indian scenario: A review. Chemosphere 2018, 213, 333-344. [CrossRef]

32. Ahmaruzzaman, M. A review on the utilization of fly ash. Prog. Energy Combust. Sci. 2010, 36, 327-363. [CrossRef]

33. Komljenović, M.; Petrašinović-Stojkanović, L.; Baščarević, Z.; Jovanović, N.; Rosić, A. Fly ash as the potential raw mixture component for Portland cement clinker synthesis. J. Therm. Anal. Calorim. 2009, 96, 363-368. [CrossRef]

34. Lechtenbergy, D. Power Plant Ashes as Substitute Raw Materials. Global Cement Magazine. 2012. Available online: https: //www.globalcement.com/magazine/articles/735-power-plant-ashes-as-substitute-raw-materials (accessed on 5 April 2021).

35. Kourti, I.; Delgado Sancho, L.; Schorcht, F.; Roudier, S.; Scalet, B.M.; Joint Research Centre, Institute for Prospective Technological Studies. Best Available Techniques (BAT) Reference Document for the Production of Cement, Lime and Magnesium Oxide: Industrial Emissions Directive 2010/75/EU (Integrated Pollution Prevention and Control). Publications Office. 2013. Available online: https: / / data.europa.eu/doi/10.2788/12850 (accessed on 7 January 2022).

36. Cembureau The European Cement Association. Activity Report, Brussels. 2020. Available online: http://www.cembureau.eu/ library/reports / (accessed on 7 January 2022).

37. EN 450-1:2012; Fly Ash for Concrete. Definition, Specifications and Conformity Criteria. British Standards Institution: London, UK, 2012.

38. EN 197-1:2011; Cement-Part 1: Composition, Specifications and Conformity Criteria for Common Cements. British Standards Institution: London, UK, 2011.

39. ACI Committee 232. Use of Fly Ash in Concrete; ACI 232.2R-96; American Concrete Institute: Farmington Hills, MC, USA, 1996.

40. Mehta, P.K.; Monteiro, P.J. Concrete: Microstructure, Properties and Materials, 2nd ed.; McGraw-Hill: New York, NY, USA, 2006.

41. Hashmi, A.F.; Shariq, M.; Baqi, A. An investigation into age-dependent strength, elastic modulus and deflection of low calcium fly ash concrete for sustainable construction. Constr. Build. Mater. 2021, 283, 122772. [CrossRef]

42. Hashmi, A.F.; Shariq, M.; Baqi, A.; Haq, M. Optimization of fly ash concrete mix-A solution for sustainable development. Mater. Today Proc. 2020, 26, 3250-3256. [CrossRef]

43. Elsageer, M.; Millard, S.; Barnett, S.J. Strength development of concrete containing coal fly ash under different curing temperature conditions. In Proceedings of the World of Coal Ash (WOCA) Conference, Lexington, KY, USA, 4-7 May 2009.

44. Dong, P.S.; Tuan, N.V.; Thanh, L.T.; Thang, N.C.; Cu, V.H.; Mun, J.-H. Compressive Strength Development of High-Volume Fly Ash Ultra-High-Performance Concrete under Heat Curing Condition with Time. Appl. Sci. 2020, 10, 7107. [CrossRef]

45. Jitchaiyaphum, K.; Sinsiri, T.; Chindaprasirt, P. Cellular Lightweight Concrete Containing Pozzolan Materials. Procedia Eng. 2011, 14, 1157-1164. [CrossRef]

46. Liu, X.; Ni, C.; Ji, H.; Tan, S.; Hong, B. Construction Techniques and Quality Test and Evaluation of Lightweight Cellular Concrete Mixed with Fly Ash as Subgrade Material. Adv. Mater. Sci. Eng. 2019, 2019, 5402679. [CrossRef]

47. Sasovsky, T.A.; Chorna, I.V.; Shalay, S.V.; Lysiak, O.M. Methods of cellular concrete production using fly ash. Bull. Odessa State Acad. Civ. Eng. Archit. 2021, 82, 114-122. [CrossRef]

48. Zorić, D.; Lazar, D.; Rudić, O.; Radeka, M.; Ranogajec, J.; Hiršenberger, H. Thermal conductivity of lightweight aggregate based on coal fly ash. J. Therm. Anal. Calorim. 2012, 110, 489-495. [CrossRef]

49. Nadesan, M.S.; Dinakar, P. Mix design and properties of fly ash waste lightweight aggregates in structural lightweight concreto. Case Stud. Constr. Mater. 2017, 7, 336-347. [CrossRef]

50. Little, M.R.; Adell, V.; Boccaccini, A.R.; Cheeseman, C.R. Production of novel ceramic materials from coal fly ash and metal finishing wastes. Resour. Conserv. Recycl. 2008, 52, 1329-1335. [CrossRef] 
51. Shen, B.; Poulsen, B.; Xun, L.; Qin, J.; Thiruvenkatachiru, R.; Yi, D. Remediation and Monitoring of Abandoned Mines. Int. J. Min. Sci. Technol. 2017, 27, 803-811. [CrossRef]

52. Strozik, G. The use of Fly Ash for Filling of Shallow Underground Ore Mine Workings on the Example of Mine Area Reclamation in Piekary Ślaskie. Gospod. Surowcami Miner.-Miner. Resour. Manag. 2018, 34, 139-154. [CrossRef]

53. vom Berg, W.; Feuerborn, H.-J. Coal Combustion Products in Europe-Valuable raw materials for the construction industry. Concr. Plant Int. 2006, 4, 54-62.

54. Directive 2004/42/CE of the European Parliament and of the Council of 21 April 2004 on the Limitation of Emissions of Volatile Organic Compounds Due to the Use of Organic Solvents in Certain Paints and Varnishes and Vehicle Refinishing Products and Amending Directive 1999/13/EC. Available online: https:/ / eur-lex.europa.eu/legal-content/EN/TXT/HTML/?uri=CELEX: 32004L0042\&from=PL (accessed on 9 November 2021).

55. Code of Federal Regulations 40: Protection of Environment, Chapter 1: Environmental Protection Agency, Subchapter C: Air Programs, Part 51: Requirements for Preparation, Adoption, and Submittal of Implementation Plans, Subpart F: Procedural Requirements. Available online: https:/ /www.ecfr.gov/cgi-bin/text-idx?SID=387a1dbfd3f26c488ff218f51bc0dc3f\&mc=true\& tpl=/ecfrbrowse/Title40/40CIsubchapC.tpl (accessed on 19 February 2020).

56. Nasini, L.; De Luca, G.; Ricci, A.; Ortolani, F.; Caselli, A.; Massaccesi, L.; Regni, L.; Gigliotti, G.; Proietti, P. Gas emissions during olive mill waste composting under static pile conditions. Int. Biodeterior. Biodegrad. 2016, 107, 70-76. [CrossRef]

57. US EPA. Initial List of Hazardous Air Pollutants with Modifications. Available online: https://www.epa.gov/haps/initial-listhazardous-air-pollutants-modifications (accessed on 21 February 2020).

58. Benzene. IARC Monographs on the Evaluation of Carcinogenic Risks to Humans; International Agency for Research on Cancer: Lyon, France, 2017; Volume 120. Available online: https: / / publications.iarc.fr / Book-And-Report-Series/Iarc-Monographs-On-TheIdentification-Of-Carcinogenic-Hazards-To-Humans/Benzene-2018 (accessed on 21 February 2020).

59. Directive 2009/30/EC of the European Parliament and of the Council of 23 April 2009 Amending Directive 98/70/EC as Regards the Specification of Petrol, Diesel and Gas-Oil and Introducing a Mechanism to Monitor and Reduce Greenhouse Gas Emissions and Amending Council Directive 1999/32/EC as Regards the Specification of Fuel Used by Inland Waterway Vessels and Repealing Directive 93/12/EEC. Available online: https:/ / eur-lex.europa.eu/legal-content/EN/TXT/HTML/?uri=CELEX: 32009L0030\&from $=$ PL (accessed on 9 November 2021).

60. Gross, S.A.; Avens, H.J.; Banducci, A.M.; Sahmel, J.; Panko, J.M.; Tvermoes, B.E. Analysis of BTEX groundwater concentrations from surface spills associated with hydraulic fracturing operations. J. Air Waste Manag. Assoc. 2013, 63, 424-432. [CrossRef] [PubMed]

61. Farshad, A.; Oliaei, H.K.; Mirkazemi, R.; Bakand, S. Risk assessment of benzene, toluene, ethyl benzene and xylenes (BTEX) in pain plants of two automotive industries in Iran by using the coshh guideline. Eur. Sci. J. 2013, 9, 270-276. [CrossRef]

62. Masekameni, M.D.; Moolla, R.; Gulumian, M.; Brouwer, D. Risk Assessment of Benzene, Toluene, Ethyl Benzene, and Xylene Concentrations from the Combustion of Coal in a Controlled Laboratory Environment. Int. J. Environ. Res. Public Health 2019, 16, 95. [CrossRef] [PubMed]

63. Cuiting, Y.; Guang, M.; Yunhong, P.; Qibin, X.; Junliang, W.; Zhong, L.; Jing, X. Abatement of various types of VOCs by adsorption/catalytic oxidation: A review. Chem. Eng. J. 2019, 370, 1128-1153. [CrossRef]

64. Miri, M.; Rostami Aghdam Shendi, M.; Ghaffari, H.R.; Ebrahimi Aval, H.; Ahmadi, E.; Taban, E.; Gholizadeh, A.; Yazdani Aval, M.; Mohammadi, A.; Azari, A. Investigation of outdoor BTEX: Concentration, variations, sources, spatial distribution, and risk assessment. Chemosphere 2016, 163, 601-609. [CrossRef] [PubMed]

65. Dehghani, M.; Fazlzadeh, M.; Sorooshian, A.; Tabatabaee, H.R.; Miri, M.; Baghani, A.N.; Delikhoon, M.; Mahvi, A.H.; Rashidi, M. Characteristics and health effects of BTEX in a hot spot for urban pollution. Ecotoxicol. Environ. Saf. 2018, 155, 133-143. [CrossRef] [PubMed]

66. Andreoni, V.; Gianfreda, L. Bioremediation and monitoring of aromatic-polluted habitats. Appl. Microbiol. Biotechnol. 2007, 76, 287-308. [CrossRef]

67. Zhu, C.; Jia, X.; Zhang, P.; Ye, J.; Wang, H. Cement Stabilization/Solidification of Heavy Metal-Contaminated Sediments Aided by Coal Fly Ash. Glob. Environ. Eng. 2017, 4, 46-54. Available online: https://www.avantipublishers.com/jms/index.php/tgevnie/ article/view/937 (accessed on 9 January 2022).

68. Paria, S.; Yuet, P.K. Solidification-stabilization of organic and inorganic contaminants using portland cement: A literature review. Environ. Rev. 2006, 14, 217-255. [CrossRef]

69. Hauashdh, A.; Mohamed, R.M.S.R.; Jailani, J.; Rahman, J.A. Stabilization of Peat Soil Using Fly Ash, Bottom Ash and Portland Cement: Soil Improvement and Coal Ash Waste Reduction Approach. IOP Conf. Ser. Earth Environ. Sci. 2020, $498,012011$. [CrossRef]

70. Blackman, W.C. Basic Hazardous Waste Management, 3rd ed.; CRC Press: Boca Raton, FL, USA, 2001.

71. Natali Sora, I.; Pelosato, R.; Botta, D.; Dotelli, G. Chemistry and microstructure of cement pastes admixed with organic liquids. J. Eur. Ceram. Soc. 2002, 22, 1463-1473. [CrossRef]

72. Karamalidis, A.K.; dan Voundrias, E.A. Cement-based Stabilization/solidification of Oil Refinery Sludge Leaching Behavior of Alkanes and PAHs. J. Hazard. Mater. 2007, 148, 122-135. [CrossRef] [PubMed]

73. Vipulanandan, C. Effect of Clays and Cement on the Solidification/Stabilisation of Phenol-Contaminated Soils. Waste Manag. 1995, 15, 399-406. [CrossRef] 
74. Butler, L.G.; Owens, J.W.; Cartledge, F.K.; Kurtz, R.L.; Byerly, G.R.; Wales, A.J.; Bryant, P.L.; Emery, E.F.; Dowd, B.; Xie, X. Synchrotron X-ray Microtomography, Electron Probe Microanalysis, and NMR of Toluene Waste in Cement. Environ. Sci. Technol. 2000, 34, 3269-3275. [CrossRef]

75. PN-B-04101:1984; Oznaczanie Nasiąkliwości Wodą. Polski Komitet Normalizacyjny/The Polish Committee for Standardization: Warsaw, Poland, 1984.

76. Banaszkiewicz, K.; Marcinkowski, T. Cementation as a method of remediation of soil contaminated with xylene. Environ. Prot. Eng. 2014, 40, 57-66. [CrossRef]

77. Banaszkiewicz, K.; Badura, M. Experimental investigation on the application of recycled tires polymer fibers as a BTEX removal material. SN Appl. Sci. 2019, 1, 558. [CrossRef]

78. Senthil Kumar, M.; Sivasankar, V.; Gopalakrishna, G.V.T. Quantification of benzene in groundwater sources and risk analysis in a popular South Indian Pilgrimage City-A GIS based approach. Arab. J. Chem. 2017, 10, S2523-S2533. [CrossRef]

79. Logeshwaran, P.; Megharaj, M.; Chadalavada, S.; Bowman, M.; Naidu, R. Petroleum hydrocarbons (PH) in groundwater aquifers: An overview of environmental fate, toxicity, microbial degradation and risk-based remediation approaches Environmental. Technol. Innov. 2018, 10, 175-193. [CrossRef]

80. ATSDR. Toxicological Profile for Benzene (Update); U.S. Department of Health and Human Services, Public Health Service, Agency for Toxic Substances and Disease Registry: Atlanta, GA, USA, 2007.

81. Lake, C.B.; Arefi, G.; Yuet, P.K. Examining fly ash as a sorbent for benzene, trichloroethylene, and ethylbenzene in cement-treated soils. Can. Geotech. J. 2013, 50, 423-434. [CrossRef]

82. Sun, J.; Lin, G.; Zhu, H.; Tang, X.; Zhang, L. Study on Adsorption-Desorption of Benzene in Soil. IOP Conf. Ser. Earth Environ. Sci. 2020, 546, 042041. [CrossRef]

83. Donaldson, S.G.; Miller, G.C.; Miller, W.W. Remediation of Gasoline-Contaminated Soil by Passive Volatilization. J. Environ. Qual 1992, 21, 94-102. [CrossRef]

84. Smith, J.A.; Chiou, C.T.; Kammer, J.A.; Kile, D.E. Effect of soil moisture on the sorption of trichloroethene vapor to vadose-zone soil at Picatinny Arsenal, New Jersey. Environ. Sci. Technol. 1990, 24, 676-683. [CrossRef]

85. Bartoňová, L. Unburned carbon from coal combustion ash: An overview. Fuel Processing Technol. 2015, 134, 136-158. [CrossRef]

86. Zhao, A.; Pudasainee, D.; Duan, Y.; Gupta, R.; Liu, M.; Lu, J. A review on mercury in coal combustion process: Content and occurrence forms in coal, transformation, sampling methods, emission and control technologies. Prog. Energy Combust. Sci. 2019, 73, 26-64. [CrossRef]

87. Banaszkiewicz, K.; Marcinkowski, T. Use of cement-fly ash-based stabilization techniques for the treatment of waste containing aromatic contaminants. E3S Web Conf. 2017, 22, 00009. [CrossRef]

88. Odler, I.; Rößler, M. Investigations on the relationship between porosity, structure and strength of hydrated Portland cement pastes. II. Effect of pore structure and of degree of hydration. Cem. Concr. Res. 1985, 15, 401-410. [CrossRef]

89. Ezeldin, A.S.; Mikhail, R.; Choi, B. Properties of concrete containing benzene contaminated soil. ACI Mater. J. 1995, 92, 401-410.

90. Rafieizonooz, M.; Mirza, J.; Salim, M.R.; Hussin, M.W.; Khankhaje, E. Investigation of coal bottom ash and fly ash in concrete as replacement for sand and cement. Constr. Build. Mater. 2016, 116, 15-24. [CrossRef]

91. Saha, A.K. Effect of class F fly ash on the durability properties of concrete. Sustain. Environ. Res. 2018, 28, 25-31. [CrossRef]

92. Chen, X.; Wu, S. Influence of water-to-cement ratio and curing period on pore structure of cement mortar. Constr. Build. Mater. 2013, 30, 804-812. [CrossRef]

93. Siline, M.; Ghorbel, E.; Bibi, M. Effect of freeze-thaw cycles on the physicomechanical properties of a pozzolanic mortar. Constr Build. Mater. 2017, 134, 32-38. [CrossRef] 